\title{
Using think-aloud protocol in self-regulated reading research
}

\begin{abstract}
This paper reviews studies that have used think aloud protocol to explore self-regulated reading process. The review intends to identify its major contributions and key methodological concerns related to the use of think-aloud protocol in self-regulated reading research. It addresses the following three questions: 1) what does think-aloud protocol enable researchers to learn about self-regulated reading?; 2) what methodological concerns do researchers have when using think-aloud protocol to explore self-regulated reading?; and 3) how can these concerns be addressed when designing think-aloud protocol for self-regulated reading research? In light of this review, suggestions are provided for further discussion on methodological issues in selfregulated reading research. Such discussions will inform researchers' efforts to use think-aloud methods in self-regulated reading research.
\end{abstract}

\section{Introduction}

Reading attracts attention in research as it entails essential skills that individuals need to search for information, integrate information for understanding, as well as evaluate, critique, and use information in today's world (Grabe, 2009). Reading is a strategic process since it involves the use of different strategies such as cognitive (e.g., inference, brainstorming, reasoning) and metacognitive ones (e.g., clarifying the purposes of reading', 'monitoring ongoing activities to determine whether comprehension is occurring', and 'engaging in self-questioning to determine whether goals are being achieved') (Baker \& Brown, 1984). When individuals utilized metacognitive strategies including planning, progress monitoring and reflection to regulate the reading process (Green \& Azevedo, 2009; Pintrich \& Zusho, 2002), such reading process can be called self-regulated reading. Since self-regulation or metacognitive strategy use significantly contributes to learners' mastery of the learning content, it has attracted increasing attention in research, especially on reading, in the last three decades (Roohani \& Asiabani, 2015; Zhang, 2008). To gain understanding of readers' self-regulated reading process, researchers adopted a number of techniques, including questionnaires (e.g., Liyanage \& Bartlett, 2011), interviews (e.g., Fadlelmula, 2010), observations (e.g., Veenman \& Spaans, 2005), stimulated recall (e.g., Juliebo, Malicky \& Norman, 1998), on-line computer log file registration (e.g., Veenman, Wilhelm, \& Beishuizen, 2004), eye-movement registration (e.g., Kinnunen \& Vauras, 1995) and think-aloud protocol (e.g., Bråten \& Strømsø, 2003). While all techniques have pros and cons (Veenman et al., 2006), think-aloud has emerged to be a popular tool for researchers to access learners’ self-regulated reading process (Bråten \& Samuelstuen, 2004; Bråten \& Strømsø, 2003).

Think-aloud is a method to identify cognitive and metacognitive processes as participants are asked to talk aloud while thinking, problem solving, or learning (Ericsson \& Simon, 1993; Pressley \& Afflerbach, 1995). As Veenman (2005) observes, 'people simply don't do what they say they will do [in prospective measures], or they do not recollect accurately what they have done' in retrospective measures (p. 13). Compared to retrospective measures such as questionnaire and interview, think-aloud protocol is regarded as more accurate for capturing learners' learning processes since learners are required to report on their learning process while they are working on a particular task (Yoshida, 2008). With the development of modern techniques, methods such as on-line computer log file registration and eye-movement 
registration have been increasingly popular in cognition and metacognition research (Rayner, 2009; Veenman \& Spaans, 2005). These techniques, however, can only be used to infer cognitive/metacognitive processes according to participants' behavior (e.g., scrolling as indication of a participant's intention to check), and thus it is important for them to be used together with verbal report data so that researchers can be more confident about their conclusions (Brunfaut \& McCray, 2015). For this reason, think-aloud protocol as a traditional technique remains as an important methodological tool in cognition and metacognition research, especially on self-regulated reading. Think-aloud protocol can help researchers elicit a wide array of responses from readers related to the reading process (van den Broek, Lorch, Linderholm, \& Gustafson, 2001), which are normally silent, hidden, and cannot be easily observed or assessed through its product (Yoshida, 2008).

Given the importance of think-aloud protocol in self-regulated reading research, this paper reviews relevant self-regulated reading literature to identify its major contributions and key methodological concerns. Despite the strengths of think-aloud protocol as a data collection method, researchers have problematized their use in reading research (Pressley \& Afflerbach, 1995). In particular, when the examined reading process is metacognitive rather than cognitive, think-aloud protocol could be even more problematic as a methodoogical tool to capture the reading process (Bowles, 2010a). Therefore, the results of this review would inform researchers' efforts to use think-aloud methods in conducting relevant research as the review focuses on answering the following questions:

1) What does think-aloud protocol enable researchers to learn about self-regulated reading?

2) What methodological concerns do researchers have when using think-aloud protocol to explore self-regulated reading?

3) How can these concerns be addressed when designing think-aloud protocol for selfregulated reading research?

\section{Method}

To conduct this review, four major academic databases of linguistics, education and psychology - Linguistics and Language Behavior Abstracts (LLBA), Educational Information Resource Center (ERIC), Web of Science, and PsycInfo - were searched for scholarly journal articles, using combinations of the following keywords: "self-regulated learning”, "self-regulatory skills”, "self-regulatory strategies", and "reading” from 1980 to September 2016. All the empirical studies published in English, which reported using think-aloud protocol, were included for the analysis. Self-regulated reading studies using both think-aloud protocols and other research methods were also included but those deploying methods other than think-aloud protocol (e.g., questionnaire survey, semi-structured interviews) were excluded from the analysis. Articles discussing methodological concerns of think-aloud protocol without empirical data were consulted and informed the relevant discussions in this review, but they were not included in the data set for analysis. Backward citations were also retrieved for English empirical self-regulated reading studies where think-aloud protocols were involved. Twenty-nine papers were found in the search and these studies were grouped into two sets of studies. The first set includes six studies examining the reliability and validity of think-aloud protocol through experiments and the second set includes twenty-three studies using think-aloud protocols as data collection method. The descriptive information of the papers can be found in Appendix I. 
To answer the first question, the research findings of the 23 papers in the second set were first coded. For instance, the paper that found readers' online self-regulated reading processes differed in different online environments was coded as "different self-regulated reading processes in different environments", and the one that found self-regulated reading processes were positively related to reading outcome was coded as "self-regulated reading and reading outcome”. Then the codes were grouped based on the themes. For example, "different selfregulated reading processes in different environments", "different self-regulated reading processes in different time periods", "different self-regulated reading processes for different reading purposes" were grouped into the theme "dynamic nature of self-regulated reading”. With regard to the second research question, the findings of the experimental studies in the first set were analyzed and interpreted. To address the third research question, the findings of studies in the first set, which examine the validity of think-aloud design, were summarized, and the design of think-aloud protocol of the 23 papers in the second set were further analyzed, focusing on two techniques including training and prompting, to identify how the use of think aloud protocols can be improved to enhance its methodological rigour.

\section{Results}

\subsection{Think aloud Protocol's contributions}

Think-aloud protocol has been used in self-regulated reading research to answer a wide range of questions. Relevant answers have enriched our understanding of readers' self-regulated reading process. For example, Mateos, Martín, Villalón and Luna (2008) investigated secondary school students' self-regulated reading process. Since they found that the participants did not plan, monitor or evaluate reading, they concluded that these secondary school students lack metacognitive reading processes. In contrast, Fadlelmula's (2010) study on an experienced reader's reading process revealed that this reader went through 4 phases of self-regulated reading, including forethought, monitoring, control and reflection to take control of cognition, motivation, behavior and context in the reading process. Examinations of learnings' reading process in above-mentioned studies constitute the most popular way to use think-aloud protocol in selfregulated reading research. In addition, think-aloud protocol has been used to discuss critical issues in self-regulated reading. It explored the dynamic nature of self-regulated reading (e.g., Fadlelmula, 2010), effects of self-regulated reading on learning outcome (e.g., Bernacki, Byrnes, \& Cromley, 2012), differences between low and high performing students in terms of selfregulated reading process (e.g., Denton et al., 2015), and effective pedagogy to facilitate selfregulated reading (e.g., Azevedo, Cromley, Winters, Moos, \& Greene, 2005). These themes are elaborated in detail with sample studies in the following subsections (more information about these studies can be found in Appendix I).

\subsubsection{Dynamic nature of self-regulated reading}

One of the most noticeable contributions that think aloud protocol has made is that it helps researchers capture the dynamic nature of self-regulated reading process by comparing different think-aloud reports generated by readers at different times, in different reading environments, and for different reading purposes. For example, Bråten and Strømsø (2003) compared the same learners' think-aloud reports in different time periods to see how self-regulated reading 
developed. They conducted three sessions of think-aloud reports with first-year law students at the University of Oslo, with an interval of four weeks between sessions. The analysis of these reports revealed that the participants' use of organizing and monitoring strategies gradually increased from Session 1 to Session 3. Coiro and Dobler (2007) examined how different reading enviornments might mediate learners' self-regulated reading. In the study, they asked sixth-grade students with high reading achievements to do two reading sessions, one in a multi-layer website and the other in a search engine context. The comparison of the participants' think aloud protocols in online reading and printed text contexts showed that the participants displayed much more complex self-regulated information seeking behaviours during online reading. Research has been also conducted to document the self-regulated reading processes when learners read for different purposes. Linderholm and Broek's (2002) study on university students, who were randomly assigned to read for entertainment or read for study, identified that readers reported more use of metacognitive strategies when reading to study than when reading for entertainment. These studies through the use of think aloud protocols reveal that self-regulated reading process is dyamic across time, responsive to contextual conditions and varies according to reading purposes.

\subsubsection{Effects of self-regulated reading on learning outcome}

Researchers have relied on think aloud protocols to investigate the effects of self-regulated reading on learning outcome. For instance, Barnett (1998) found self-regulated reading strategies, elaboration and monitoring positively correlated with reading outcomes and the students who effectively self-regulated in the reading process received the highest grades in the study. Azevedo, Guthrie, and Seibert (2004) probed into the role of self-regulated reading in facilitating undergraduate students' learning of a scientific topic, the circulatory system, in a hypermedia context. Again the results confirmed that students with high gains were much better at regulating their reading by using effective strategies, planning the reading process (i.e., setting goals, allocating time and managing efforts) and monitoring their understanding. In contrast, students with low gains were found to have not used strategies effectively. When these students had difficulties, they were more inclined to seek help rather than monitoring their own reading. In another study, Greene and Azevedo (2009) examined how different self-regulated reading processes were associated with secondary school students' understanding of a complex biological system in a hypermedia environment. Findings suggested that monitoring was a key self-regulated reading process for the development of an understanding of a complex science topic in hypermedia environments. Moreover, Azevedo, Greene, and Moos (2007) compared the effects of self-regulated reading and self-regulated reading facilitated by tutors on university students' performance when reading to learn about a scientific topic. The study showed that when self-regulated reading was facilitated by tutors, students performed significantly better than the group without tutor facilitation. This means that teachers also have an important role in facilitating students' self-regulated reading.

\subsubsection{Comparison between low and high performing students}

For many decades, it has been believed that what good learners do can be taught to poorer learners to enhance their learning performance (Griffiths, 2015). Think-aloud protocol helps researchers gain insights into the differences between under-performing and high-performing readers in the self-regulated reading process. These insights are crucial to the development of 
pedagogical interventions that develop under-performing readers' capacity for better selfregulated reading. For instance, Denton et al. (2015) found that under-performing students reportedly used significantly less of monitoring strategies in reading than high performing ones. In Bråten \& Strømsø's (2003), the highest performing students were found to have used more self-regulated reading strategies, such as organization and monitoring, whereas under-performing students reported greater use of cognitive strategies, such as memorization and elaboration strategies. In the study, the highest performing students were also found to have increased the use of monitoring strategies over time but under-performing students decreased the use of monitoring strategies instead. Echoing such findings, Goldma, Braasch, Wiley, Graesser, and Brodowinska (2012) also found that good readers engaged more in monitoring processes than under-preforming readers did. It is not surprising thatgood readers were also found in the study to have been engaged more in goal-directed navigation activities. Proficient readers not only reported having used more strategies but they were also found to have used strategies more effectively than under-performing readers in Jiménez, García, and Pearson's (1995) comparison of one proficient and one underperforming reader's self-regulated reading process through analyzing think-aloud reports. Slightly different from the above studies, Linderholm and van den Broek (2002) compared reading processes of low and high working memory capacity (WMC) readers. They found that low-WMC readers made fewer metacognitive comments while reading to study than high-WMC readers did, but the two groups of readers shared similar processes while reading for entertainment. This result confirms that learners' self-regulated reading process is dynamic and context-dependent.

\subsubsection{Effective pedagogy to facilitate self-regulated reading}

Due to the important role self-regulated reading processes play in learning, researchers attempt to find out whether those processes can be taught and how they can be improved through pedagogoic interventions. Think-aloud protocol has proved to be highly instrumental in eliciting the self-regulated reading processes before and after the relevant pedagogical intervention so that the effects of these interventions can be captured through comparison. In Rogers' (1991) study, an instructional unit was provided to 8 nineth-grade students. During the pedagogical intervention, students were encouraged to participate in a literature reading process in 3 classes. They were asked to read a story and interpret it before they shared and discussed interpretations with peers to construct a final interpretation. The discussion phase was designed to give students more inputs for the reading process and strategy use. It was initially based on students' responses to their interpretation of the story and then on critiques published in literary journals. An extra text was also used in the discussion to increase students' awareness of different reading processes. At last, students were encouraged to reflect and reexamine their respective interpretations. Student's think-aloud protocols were used to analyze the self-regulated reading processes. The results showed that after participating in the instructional unit, students used more self-regulated strategies while reading, such as questionning and evaluating. Moos and Azevedo (2008) examined the impact of conceptual scaffolds like monitoring and planning on 37 undergraduates' use of self-regulated reading processes. Results indicated that students who were provided with conceptual scaffolds used more of planning during the hypermedia reading task than students who were not provided with the scaffolds. As mentoined earlier, Azevedo, Moos, Greene, Winters, and Cromley (2008) found that learners used the self-regulated reading processes more effectively when their self-regulated reading was facilitated by tutors. Compared 
to the learners who were not given the facilitation, the group with the facilitation was found to be engaged in more monitoring activities, to deploy the strategies more effectively, and to engage in adaptive help seeking.

\section{2 . Methodological concerns in using think aloud protocols}

As think-aloud protocol becomes a popular methodological choice to capture learners' cognitive and metacognitive process, researchers have also found it challenging to collect data through think-aloud protocol because its actual administration is time-consuming and labor-intensive (Barkaoui, 2011; Bråten \& Samuelstuen, 2004). There are also major methodological concerns, including reactivity and veridicality. Reactivity concerns whether reporting cognitive/metacognitive processes alters the processes being reported (e.g., reading process) and/or its outcomes (e.g., comprehension or remembering of reading texts), while veridicality concerns whether the cognitive/metacognitive processes can be accurately and completely reported (Bowles, 2010b; Ericsson \& Simon, 1993; Pressley \& Afflerbach, 1995). We focus on the two major methodological concerns in the subsequent sections.

\subsubsection{Reactivity of think-aloud protocol in self-regulated reading}

Research has been conducted to see whether think-aloud participants and participants who complete the tasks silently perform differently in terms of accuracy (whether participants' reading processes or reading outcomes are altered) and latency (whether participants' reaction time increases) (see Bowles, 2010a for a meta-analysis). These studies yielded inconclusive results, indicating that the reactive effects of think-aloud are moderated by a number of variables, including type of report (e.g., metacognitive and non-metacognitive), language of verbal report or learning task (e.g., L1 and L2, reading) (Bowles, 2010b), and age of participants. Bowles (2010a) suggests that think-aloud will have greater reactive effects when the learning task is reading and when the type of report is metacognitive. For this reason, in self-regulated reading research using think-aloud, where participants need to produce metacognitive verbal reports while doing reading tasks, researchers do need to carefully consider the reactive effects of thinkaloud protocol on the reading process (Greene \& Azevedo, 2009; Yoshida, 2008). Three studies have compared students' self-regulated reading with and without think-aloud to examine the reactive effects of think-aloud on self-regulated reading processes and/or students' reading outcomes. Baumann, Seifert-Kessell, and Jones (1992) investigated whether think-aloud affected fourth-grade students' L1 comprehension monitoring process when reading a story and their

performance in an error detection test and a cloze test. Participants were asked to think aloud to report their monitoring process while reading and the monitoring process was compared with that of participants without thinking-aloud. The former group was found to be more skillful in comprehension monitoring and to perform better in the reading tests, suggesting that think-aloud might have altered the monitoring process and learning outcomes in a positive way. The other two studies have yielded contradictory results on the reactive effects of reporting metacognitive process on reading outcomes. Bannert and Mengelkamp (2008) found that reading outcomes of university students who were involved in metacognitive verbalization was not significantly different from those of students who were involved in cognitive verbalization and non verbalization activities, which means metacognitive verbalization did not alter self-regulated reading outcomes. Yoshida's (2008) study also showed no change of self-regulated reading 
outcomes (i.e., amount of information recalled) by meta-cognitive verbalization, after he compared the reading performance of university students who were asked to verbalize what they were thinking and those in the non-think-aloud group. As the type of report (i.e., metacognitive) and type of task (i.e., reading) were the same for the aforementioned three studies, the language of reading task (e.g., L1 and L2), another factor of think-aloud reactivity found in Bowles (2010b), is therefore necessarily taken into consideration to explain the inconclusive results. The findings of Baumann and colleagues (1992) where L1 was used for the reading task indicated that verbalizing in L1 may improve learning outcome (Bowles, 2010b). Besides, as assumed by Afflerbach and Johnston (1984), different ages of participants may lead to different extents of influence by think-aloud reactivity. In the above three experiments, the participants were of different ages. Those in Baumann et al. (1992) were fourth-grade students while those in the other two were university students. It can be argued that younger participants may more easily alter their reading process while thinking aloud and therefore age of participants may be a moderator of think-aloud reactive effects. More experiments are needed to confirm these findings.

Only one study (Yoshida, 2008) was found to have investigated the effect of think-aloud task on the time spent on self-regulated reading. It calculated the mean proportion and standard deviations of the time the participants spent for reading and task completion. The results showed that the think-aloud group took considerably more time than the non-think-aloud group, which suggested that reporting meta-cognition aloud had a significant effect on the amount of time spent for completing reading tasks. Such results have important methodological implications. Since research has generally shown that thinking aloud generally increases the time participants spend on completing a given task, it is suggested that when reaction time is a dependent variable under investigation, think-aloud protocol should not be used (Bowles, 2010b).

\subsubsection{Veridicality of think-aloud protocol in self-regulated reading}

Although think aloud protocol has been used to access readers' reading process, researchers have also begun to question its veridicality as a methodological tool to capture learners' cognitive processes (Rogers, Révész, \& Rebuschat, 2016). Think-aloud protocol has been criticized for the potential of inaccurate and incomplete reflection of learners' thoughts (Barkaoui, 2011; Ericsson \& Simon, 1993). Fewer studies have been conducted to examine the veridicality of think-aloud protocol (Yang \& Zhang, 2015), in comparison with those on reactive effects. This noticeable lack of research on the veridicality issue might have been associated with a popular belief that concurrent protocols, including think-aloud, are not subject to the same veridicality risks as retrospective protocols are. Those who are in favor of think-aloud protocol have consistently argued that since the verbalization occurs during the task, it is impossible for the reporters to forget the cognitive and metacognitive process and thus they can report their thoughts completely. Bowles and Leow (2005) note, "some evidence for nonveridicality has been found for retrospective protocols, which can 'yield substantial forgetting or fabrication in all tasks'...Concurrent protocols, on the other hand, are not subject to the same critique, as they are collected during the task" (p. 417). Robinson (2001) also argues, "[during] concurrent reports (CRs), or thinking aloud or talking aloud...processing and verbalization occur at the same time and, therefore, no thought, feeling, or action would be omitted because the participant has not had time to forget” (p. 211). However, time is not the only factor that can undermine the quality of data collection. Unclear instructions given for think-aloud tasks, cultural differences between 
the researcher and participants, and individual differences such as gender and learning styles may all contribute to incomplete or inaccurate verbalization (Barkaoui, 2011). Therefore, veridicality issue of think-aloud cannot be ignored.

Three studies have examined the completeness of think-aloud reports used to access selfregulated reading processes. In Scott's (2008) study, data of the reading process were collected from fourth-grade students through think-aloud, interview, error detection or questionnaire. Results indicated that the participants in the think-aloud group reported a larger number and a broader range of self-regulated reading strategies, particularly metacognitive reading strategies. These results indicate that think-aloud protocol showed more veridicality in terms of accessing self-regulated reading processes, compared to the other three measurement methods (i.e. interview, error detection or questionnaire). However, although the study indicates that thinkaloud protocol can elicit more verbalization of self-regulated processes than other methods do, it does not necessarily guarantee that think-aloud reports can capture all the processes. Branch's (2001) study looked at the coverage of think-aloud verbal reports generated by Canadian junior high students during the process of self-regulated reading for seeking information. Findings showed that some participants had difficulties in verbalizing their metacognition during reading. It concluded that when participants were not familiar with the learning task, they were unable to think aloud while doing the task. In Barkaoui's (2011) survey, many adult participants reported that they were not able to verbalize all of their thoughts during think-aloud tasks or only reported things they thought were important, because some thoughts were automatic, certain processes were too complex to be reported, or they thought that the "trivial" and "irrelevant" things should not be reported.

Overall, we are concerned with this lack of discussion on veridicality of think-aloud protocol as we noticed that many self-regulated reading studies do not discuss the limitations of thinkaloud protocol in terms of veridicality (e.g., Azevedo, Cromley, \& Seibert, 2004; Azevedo, Guthrie, \& Seibert, 2004; de Milliano, Gelderen, \& Sleegers, 2016; Narvaez, van den Broek, \& Ruiz, 1999). We believe that it is important for researchers interested in self-regulated reading processes to consider the potential pitfalls that think aloud-protocols have and design think-aloud tasks more carefully to capture learners' reading processes fully. Alternatively, we may adopt the view advanced by Cumming, Kantor and Powers (2002) that think-aloud data are only indicators of part of the reading processes.

\subsection{Design of think-aloud tasks for self-regulated reading research}

As discussed above, the methodological rigour of think-aloud protocol is influenced by a number of variables, including type of report, language of verbal report or learning task, type of task, participants' age, and instruction of think-aloud, etc. (Afflerbach \& Johnston, 1984; Barkaoui, 2011; Bowles, 2010b). Therefore, it is premature to jump to the conclusion that think-aloud protocol is not valid for researchers to capture individual readers' metacognitive processes while reading. Baumann et al (1992) and Yoshida's (2008) study indicate that under certain circumstances, the reactivity risk of think-aloud protocol in self-regulated reading research can be minimized. Two self-regulated reading studies examined through experiments the effects of think-aloud design on its methodological rigour. Studies relying on the use of think aloud protocols often include ideas of how to minimize the reactivity effects and maximize the veridicality. In the reviewed studies, training and prompting were two of the most highlighted 
strategies to improve think-aloud protocol's methodological rigour. The pros and cons of training and prompting in terms of think-aloud validity are elaborated in this section.

\subsubsection{Training}

Providing training sessions helps participants get familiar with think-aloud tasks, and hence the increase of think-aloud validity (Afflerbach \& Johnston, 1984; Bowles, 2010b; Branch, 2001). Instruction is a commonly suggested training technique. As unclear instruction of think-aloud tasks may contribute to incomplete verbalization (Barkaoui, 2011), instruction should cover reasons why participants are being asked to think aloud and ways they should think aloud (Bowles, 2010b). It is also important for researchers to ask readers to make self-reports as accurate and complete as possible by talking about both what they are doing while reading and why they are doing so (Pressley \& Afflerbach, 1995). In the reviewed studies, 15 of them (23) required readers to report whatever they are thinking about while reading (e.g., Azevedo, Cromley, et al., 2004; Azevedo et al., 2005; Azevedo et al., 2008; Azevedo, Guthrie, et al., 2004; Bråten \& Strømsø, 2003), where words such as 'whatever', 'everything', or 'anything' were used in the instruction. Three of the 23 studies (Coiro \& Dobler, 2007; Kendeou \& van den Broek, 2007; de Milliano et al., 2016) still asked readers to explain their behaviors, but they did not use the aforementioned words in the instruction for think-aloud tasks. However, some researchers (e.g., Chuang, 2007; Pressley \& Afflerbach, 1995) noted the potential risk of instructing readers to justify or to explain in think-aloud, contending that such practice may lead to significant reactive effects on participants' reading outcome and reading processes. Their concern was confirmed in Baumann, Seifert-Kessell, and Jones (1992) experiment on think-aloud reactive effects where positive effects of justification or explanation were found on readers' reading process and outcome. For this reason, the instruction in two of the collected self-regulated reading research, Barnett (1998) and Fadlelmula (2010), discouraged readers to justify or explain their reading behaviors during think-alouds.

Demonstration and practice are also suggested training techniques for think-aloud. In the reviewed self-regulated reading studies, five have a demonstration session on how to do thinkaloud protocol to the participants prior to the actual administration of think-aloud. Jiménez et al. (1995) and de Milliano et al. (2016) used videotapes or demo clips to show what the process of thinking aloud while reading was like. Denton et al. (2015) demonstrated think-aloud procedure by acting it out themselves. Goldma et al. (2012) and Narvaez et al. (1999) presented illustrative comments that one could make on reading so that participants knew what exactly they were expected to say aloud. Bowles (2010b) suggests that it is important for the participants to have opportunities of practicing think-aloud protocol and asking questions about the procedures during practice. That may be why 14 studies explicitly allowed participants to practice before they thought aloud. While acknowledging the importance of demonstration and practice in enhancing the quality of research evidence, researchers are also aware of the procedure's risk of engaging participants in verbalizing what is not in the mind. They contend that practice task "should be carefully chosen so that it does not prime the participants for the target structure being investigated in the study" (Bowles, 2010b, p. 117). It is suggested that think-aloud tasks used for demonstration should be different from those under investigation and all participants should be given the same examples to reduce the risk of bias(Branch, 2001; Denton et al., 2015). Four of the 26 studies described the texts used for practice and all of them used texts different from those used for tasks under investigation. For practice, Barnett (1998) used an informative 
writing text, while in the main think-aloud task an expository text was used. The other three studies (i.e., Bråten \& Strømsø, 2003; Denton et al., 2015; Goldma et al., 2012) chose texts of the same genre but different topics for the practice. For example, in Bråten and Strømsø’s (2003) study, the students were given texts that were not related to law during the practice session, while law-related texts were provided for verbal reports. However, both texts were expository. Another concern regarding practice is its potential of turning readers' cognition into something automatic that cannot be verbalized. That is why participants should not be given too much practice unless they do not appear to verbalize as much as normal learners. However, as noted by Branch (2001), how much practice should be given is hard to ascertain and requires further research to verify.

\subsubsection{Prompting}

As it often happens in think-aloud research, participants forget to verbalize during think-aloud when they are absorbed in the learning task (Afflerbach \& Johnston, 1984). To collect rich data about reading processes, it is important to constantly remind participants to report their thoughts by using prompting questions (Afflerbach \& Johnston, 1984; Bowles, 2010b). Despite its critical role, prompting could be also considered interference with the reading process being observed (Afflerbach \& Johnston, 1984). To protect the reading process from interference of prompting, Fadlelmula (2010) avoided prompting readers during think-aloud sessions. He took notes and asked follow-up questions after the think-aloud protocol. Realizing both advantage and potential risk of prompting, researchers prompted in training sessions rather than data collection sessions in three studies (Jiménez et al., 1995; Kendeou \& van den Broek, 2007; Narvaez et al., 1999). However, majority of the reviewed self-regulated reading studies (19 out of 23) prompted during the reading tasks being observed. The prompting included "What are you thinking right now?", "Please say what you are thinking," "Don't forget to read out loud," "Say what you are looking for now" or "why are you clicking there" etc. Placing markers in the texts as a prompting technique was thought to be a way to reduce the reactive effects of prompting on reading performance, while reminding students to retain cognitive space for thinking processes" (Scott, 2008, p. 300). Crain-Thoreson, Lippman, and McClendon-Magnuson (1997) compared marked and unmarked think-alouds and found that the marked procedure elicited more veridical protocols and therefore it is a valid technique to strengthen the rigour of think aloud research. Scott (2008) found that the four markers placed at transition points or between events in the story enabled participants to think aloud with little interference in the reading process. Cromley and Azevedo (2006) used embedded red dots in the texts, after each sentence, to remind readers to think aloud so that they could compare the validity of think-aloud protocols with that of prospective self-report measure and concurrent multiple-choice measure in identifying cognitive and meta-cognitive strategies used by the participants.

\section{Discussion}

Like all the other techniques for elicitation of cognitive/metacognitive processes, think-aloud protocol has its own limitation. For instance, individual readers may be no longer conscious of certain metacognitive processes when they become regulatory habits (Veenman, van HoutWolters, \& Afflerbach, 2006). In this case, it is impossible for the readers to verbalize them, and thus think-aloud protocol cannot be used as an effective tool alone. However, the fact that researchers have revealed a wide range of self-regulated reading process with think-aloud 
protocol indicates that it is still a powerful tool for self-regulated reading research, provided that its validity issues are carefully considered and addressed.

Think-aloud protocol may probably have high reactivity risks in self-regulated reading research due to the high cognitive demands caused by reporting meta-cognition and cognition. We therefore contend that the reactive effects of think-aloud protocol should be considered more carefully in self-regulated reading research. However, as mentioned earlier, only a few studies have examined the reactivity of think-aloud in self-regulated reading, and the results are not yet conclusive. These controversial findings may be due to some variables, such as language of verbal report and learning tasks (Bowles, 2010b) and age of participants (Afflerbach \& Johnston, 1984). Therefore, more research is needed to examine the reactive effect of think-aloud protocol on self-regulated reading under different conditions, involving participants of different ages, using either L1 or L2 to read and to verbalize.

The information of language of reading and verbal report was found missing in most of the self-regulated reading research where think-aloud protocol was used (Appendix I), indicating that its potential effects on think-aloud validity might not have been attached sufficient importance by self-regulated reading researchers. In addition, we argue that veridicality of thinkaloud protocol should also receive further attention, like the issue of reactivity. Although we agree with the researchers (e.g., Bowles \& Leow, 2005; Robinson, 2001) who note that the potential for participants to forget their thoughts while thinking aloud is much less than when they do retrospective protocols, we do not think that guarantees comprehensive coverage of think-aloud reports. Different factors may also contribute to incomplete verbalization, such as unclear instruction of think-aloud tasks and cultural and individual differences between researchers and participants (Barkaoui, 2011). While it is shown that think-aloud protocol generates more verbalization of self-regulated reading processes (Scott, 2008), participants have difficulties in verbalizing metacognition during reading (Branch, 2001) and thus they are not able to verbalize all thoughts during think-aloud tasks (Barkaoui, 2011). In light of these methodological concerns, we suggest that future studies provide detailed descriptions such as the languages used for reading and verbalizing as well as age of participants, and researchers need to consider these variables carefully when discussing relevant methodological limitations.

Experiment results show that when think-aloud protocols are well designed, their validity risks can be reduced (Baumann et al., 1992; Yoshida, 2008). Training participants to think aloud before reading tasks can help to improve think-aloud validity. Instruction, demonstration, and practice are possible techniques for the training of think-alouds. An issue that is worth discussion is the type of verbalization required. A large percentage of the reviewed studies that did not discourage participants to verbalize their justification or explanation for their reading behaviors indicate that such elicitation is inevitable for self-regulated reading research. There is an exception when differences between participants' cognitive rather than metacognitive strategies over a period of time serve as indicators of learning monitoring and controlling (Barnett, 1998). Despite the inevitability, researchers should be very careful when instructing participants to justify or explain while thinking aloud which may lead to significant reactive effects on participants' reading outcomes or reading process. We suggest that researchers discourage readers from justifying or explaining in the instruction and ask for justification or explanation only in the follow-up interview (see, Fadlelmula, 2010). Although demonstration and practice are useful techniques for researchers to reduce the latency of think-aloud protocol and to increase the completeness of verbalization, researchers should bear in mind that demonstration and practice may also lead to the risk of verbalizing what are not originally in participants' minds 
(Bowles, 2010b). Several techniques can be used to reduce such risk, as they were used in the reviewed studies, including using tasks other than reading, using different reading texts, and giving all participants the same examples for demonstration or practice. Besides, researchers should also be aware that over-demonstrating or practicing can lead to automatization of participants' reading process which makes the process not verbalizable. How much demonstration or practice should be provided is not clear as yet, so further research is needed to find out the relationship between the amount of demonstration/ practice and that of participants' verbalization of the reading process. Besides training, prompting participants to verbalize while reading tasks is also thought helpful to enhance think-aloud validity by increasing the completeness of the verbal report. This technique again is a potential cause of the other aspect of validity - reactivity, and placing markers as prompts can reduce such risk.

In other words, the fact that the possible solutions to reactivity problems may lead to veridicality risks, and vice versa, shows the dilemma in the use of think-aloud protocols for selfregulated reading research. Therefore, we suggest researchers view think-aloud data as indicators of only a part of self-regulated reading process rather than a full picture of it. One or more other data sources such as pre- and post- interviews, questionnaires, observations, on-line computer logs, and eye-movement registration can be combined with think-aloud reports for a full picture of self-regulated reading process. Further research is needed to identify most optimal integration of different methods in capturing participants' self-regulated reading and learning processes. The possible problems of think-aloud in self-regulated reading and our suggested solutions are listed in Appendix III.

\section{Conclusion}

So far we have reviewed studies that have examined think-aloud validity for self-regulated reading research as well as studies using think-aloud protocols to explore self-regulated reading processes. We have identified in this review that think-aloud reports have been used to explore the dynamic nature of self-regulated reading, the effects of self-regulated reading on learning outcome, the differences between low and high performing students in terms of self-regulated reading process and the pedagogy for facilitating self-regulated reading. We have also noted reactivity and veridicality as significant challenges for the use of think aloud protocol in selfregulated reading research. For this reason, we have argued that training and prompting need to be properly designed and implemented to enhance the methodological rigour of using think aloud protocols in research. We are aware that new methods have been emerging to capture individual learners' cognitive process in reading and learning, but we still believe that think aloud protocol remains an important methodological tool for us to collect learners' verbal data about metacognition and gain insights into self-regulated reading process with help of other data collection tools. 
Appendix I: Descriptive information of the papers for analysis

\begin{tabular}{|c|c|c|c|c|}
\hline Paper & $\begin{array}{l}\text { Level of } \\
\text { Education }\end{array}$ & Country & $\begin{array}{l}\text { Language } \\
\text { of } \\
\text { Reading }\end{array}$ & Contribution \\
\hline $\begin{array}{l}\text { Bannert and } \\
\text { Mengelkamp } \\
\text { (2008) }\end{array}$ & University & $\begin{array}{l}\text { Not } \\
\text { indicated }\end{array}$ & $\begin{array}{l}\text { Not } \\
\text { indicated }\end{array}$ & $\begin{array}{l}\text { The reactivity of think-aloud protocol was examined in the study. Results showed } \\
\text { no reactive effects of verbalizing metacognition on reading performances. }\end{array}$ \\
\hline $\begin{array}{l}\text { Baumann et } \\
\text { al (1992) }\end{array}$ & Fourth-grade & $\begin{array}{l}\text { United } \\
\text { States }\end{array}$ & L1 & $\begin{array}{l}\text { The study examined reactivity of think-aloud on reading comprehension } \\
\text { monitoring process. The think-aloud group was found to be more skillful in } \\
\text { comprehension monitoring than other groups, suggesting that thinking aloud } \\
\text { might have altered the monitoring process in a positive way. }\end{array}$ \\
\hline Branch (2001) & Middle school & Canada & $\begin{array}{l}\text { Not } \\
\text { indicated }\end{array}$ & $\begin{array}{l}\text { The study looked at the completeness of think-aloud verbal reports generated } \\
\text { during the process of self-regulated reading for seeking information. Findings } \\
\text { showed that when learners were not familiar with the learning task, they were } \\
\text { unable to think aloud while doing the task. }\end{array}$ \\
\hline $\begin{array}{l}\text { Crain- } \\
\text { Thoreson et al } \\
\text { (1997) }\end{array}$ & University & $\begin{array}{l}\text { United } \\
\text { States }\end{array}$ & $\begin{array}{l}\text { Not } \\
\text { indicated }\end{array}$ & $\begin{array}{l}\text { The reactivity and veridicality of two think-aloud protocols with different designs } \\
\text { were examined. One is thinking aloud with marked passages and the other with } \\
\text { unmarked passages. The results showed no effect of either of the two think-alouds } \\
\text { on the reading outcome, however, the marked think-aloud elicited more veridical } \\
\text { protocols. }\end{array}$ \\
\hline $\begin{array}{l}\text { Cromley and } \\
\text { Azevedo } \\
(2006)\end{array}$ & High school & $\begin{array}{l}\text { United } \\
\text { States }\end{array}$ & L1 & $\begin{array}{l}\text { The study examined the validity of three measures on cognitive and meta- } \\
\text { cognitive strategies: prospective self-report measure, concurrent multiple-choice } \\
\text { measure, and think aloud protocols. The concurrent multiple-choice and think- } \\
\text { aloud data were both found significantly correlated with each other and with the } \\
\text { comprehension scores, while the prospective self-report data had non-significant } \\
\text { correlations with all other measures, which suggested the validity of think-aloud } \\
\text { protocol in self-regulated reading research. }\end{array}$ \\
\hline $\begin{array}{l}\text { Yoshida } \\
\text { (2008) }\end{array}$ & University & Japan & L2 & $\begin{array}{l}\text { The study investigated the effects of think-aloud on reading time and } \\
\text { comprehension. Results showed that think-aloud did not affect self-regulated } \\
\text { reading comprehension in terms of amount of information recalled, while they } \\
\text { increased reading time. }\end{array}$ \\
\hline
\end{tabular}




\begin{tabular}{|c|c|c|c|c|}
\hline Paper & $\begin{array}{l}\text { Level of } \\
\text { Education }\end{array}$ & Country & $\begin{array}{l}\text { Language } \\
\text { of } \\
\text { Reading }\end{array}$ & Contribution \\
\hline $\begin{array}{l}\text { Azevedo et al } \\
\text { (2005) }\end{array}$ & $\begin{array}{l}\text { Tenth-grade \& } \\
\text { seventh-grade }\end{array}$ & $\begin{array}{l}\text { United } \\
\text { States }\end{array}$ & $\begin{array}{l}\text { Not } \\
\text { indicated }\end{array}$ & $\begin{array}{l}\text { Effects of the three scaffolding conditions on self-regulated learning through } \\
\text { reading in a hypermedia environment were examined. Findings showed that } \\
\text { learners with adaptive scaffolding regulated their learning effectively, while } \\
\text { learners with no scaffolding used fewer effective strategies and those with fixed } \\
\text { scaffolding regulated their learning in an ineffective way. }\end{array}$ \\
\hline $\begin{array}{l}\text { Azevedo, } \\
\text { Cromley, et al } \\
(2004)\end{array}$ & Undergraduate & $\begin{array}{l}\text { United } \\
\text { States }\end{array}$ & $\begin{array}{l}\text { Not } \\
\text { indicated }\end{array}$ & $\begin{array}{l}\text { The study examined the effects of three scaffolding conditions on self-regulated } \\
\text { learning through reading: adaptive scaffolding, fixed scaffolding, and no } \\
\text { scaffolding. It revealed that learners in the adaptive scaffolding condition } \\
\text { regulated their learning more effectively than learners from the other two groups } \\
\text { did. }\end{array}$ \\
\hline $\begin{array}{l}\text { Azevedo et al } \\
\text { (2007) }\end{array}$ & Undergraduate & $\begin{array}{l}\text { United } \\
\text { States }\end{array}$ & $\begin{array}{l}\text { Not } \\
\text { indicated }\end{array}$ & $\begin{array}{l}\text { The effectiveness of self-regulated reading and tutor-facilitated self-regulated } \\
\text { reading on learning of a science topic was examined. Findings showed that } \\
\text { participants in the self-regulated reading group engaged in more use of cognitive } \\
\text { strategies while those in tutor-facilitated regulated reading group used more self- } \\
\text { regulated learning strategies such as monitoring the progress towards learning } \\
\text { goals. }\end{array}$ \\
\hline $\begin{array}{l}\text { Azevedo, } \\
\text { Guthrie, et al } \\
(2004)\end{array}$ & Undergraduate & $\begin{array}{l}\text { Not } \\
\text { indicated }\end{array}$ & $\begin{array}{l}\text { Not } \\
\text { indicated }\end{array}$ & $\begin{array}{l}\text { The study compared high-achieving learners with low-achieving learners in terms } \\
\text { of self-regulated reading strategies. The high-achieving learners were found to be } \\
\text { much better at regulating their learning through reading by effectively using } \\
\text { strategies, planning their learning, and monitoring their understanding. Low- } \\
\text { achieving learners, however, used strategies less effectively and did not spend } \\
\text { much time monitoring their learning. Despite having planned their learning, they } \\
\text { did not do it the way high-achieving learners did. }\end{array}$ \\
\hline $\begin{array}{l}\text { Azevedo et al } \\
\text { (2008) }\end{array}$ & $\begin{array}{l}\text { Middle and } \\
\text { high school } \\
\text { students }\end{array}$ & $\begin{array}{l}\text { United } \\
\text { States }\end{array}$ & L1 & $\begin{array}{l}\text { The effectiveness of self-regulated reading and tutor-facilitated self-regulated } \\
\text { reading on learners' learning of a science topic was examined. Findings showed } \\
\text { that participants in the self-regulated reading group engaged in fewer self- } \\
\text { regulated reading strategies while those in tutor-facilitated regulated reading group } \\
\text { used more self-regulated learning strategies and used them more effectively. }\end{array}$ \\
\hline Barnett (1998) & Undergraduate & $\begin{array}{l}\text { Not } \\
\text { indicated }\end{array}$ & $\begin{array}{l}\text { Not } \\
\text { indicated }\end{array}$ & $\begin{array}{l}\text { The study examined self-regulated strategies students used while reading } \\
\text { textbooks in preparation for examinations. Only three out of eight students } \\
\text { monitored their learning and showed adjustment of the strategy use across the }\end{array}$ \\
\hline
\end{tabular}




\begin{tabular}{|c|c|c|c|c|}
\hline & & & & semester. The three students got the highest scores in the examinations. \\
\hline $\begin{array}{l}\text { Bråten and } \\
\text { Strømsø } \\
(2003)\end{array}$ & Undergraduate & Norway & $\begin{array}{l}\text { Not } \\
\text { indicated }\end{array}$ & $\begin{array}{l}\text { The study examined students' self-regulated reading processes in terms of } \\
\text { comprehension confirmation, problem detection and problem solving. It found } \\
\text { that comprehension confirmation was used more by the highest performing } \\
\text { participants and the relationship between monitoring and comprehension may be } \\
\text { stronger when students read in preparation for an examination than when they read } \\
\text { in order to keep up with lectures. The other group used problem detection and } \\
\text { problem solving most during the first reading of texts, but decreased their use of } \\
\text { these strategies markedly when starting to review for the examination. }\end{array}$ \\
\hline $\begin{array}{l}\text { Coiro and } \\
\text { Dobler (2007) }\end{array}$ & Sixth-grade & $\begin{array}{l}\text { United } \\
\text { States }\end{array}$ & $\begin{array}{l}\text { Not } \\
\text { indicated }\end{array}$ & $\begin{array}{l}\text { The study explored the self-regulated reading processes of high-achievement } \\
\text { readers in online learning contexts. Results suggested that the self-regulated } \\
\text { reading processes adopted by readers in such contexts were similar and complex. }\end{array}$ \\
\hline $\begin{array}{l}\text { Denton et al } \\
\text { (2015) }\end{array}$ & $\begin{array}{l}\text { Seventh, } \\
\text { ninth, tenth, \& } \\
\text { eleventh- } \\
\text { grades }\end{array}$ & $\begin{array}{l}\text { United } \\
\text { States }\end{array}$ & $\begin{array}{l}\text { Not } \\
\text { indicated }\end{array}$ & $\begin{array}{l}\text { The study examined low- and high- achievement students' use of cognitive and } \\
\text { meta-cognitive strategies while reading two types of texts, narrative and } \\
\text { informational texts. Findings showed that low-achievement students used } \\
\text { significantly lower monitoring strategies when they read both types of texts than } \\
\text { high-achievement students when they read informational texts. }\end{array}$ \\
\hline $\begin{array}{l}\text { Fadlelmula } \\
(2010)\end{array}$ & Post-graduate & Turkey & $\begin{array}{l}\text { Not } \\
\text { indicated }\end{array}$ & $\begin{array}{l}\text { The study explored how a learner self-regulates learning while reading an } \\
\text { academic text. Results revealed that the learner went through four phases of self- } \\
\text { regulation when doing a reading comprehension task: forethought, monitoring, } \\
\text { control and reflection. }\end{array}$ \\
\hline $\begin{array}{l}\text { Goldma et al } \\
\text { (2012) }\end{array}$ & University & $\begin{array}{l}\text { United } \\
\text { States }\end{array}$ & $\begin{array}{l}\text { Not } \\
\text { indicated }\end{array}$ & $\begin{array}{l}\text { The self-regulated reading processes were compared between better learners and } \\
\text { poorer learners. Results indicated that better learners used more self-regulated } \\
\text { strategies such as sense-making, self-explanation, monitoring of comprehension } \\
\text { and goal-directed navigation. }\end{array}$ \\
\hline Greene (2007) & $\begin{array}{l}\text { Middle school } \\
\text { and high } \\
\text { school }\end{array}$ & $\begin{array}{l}\text { United } \\
\text { States }\end{array}$ & $\begin{array}{l}\text { Not } \\
\text { indicated }\end{array}$ & $\begin{array}{l}\text { The study examined the processes of learners' self-regulated learning of a science } \\
\text { topic through reading in a hypermedia context. Results indicated that high- } \\
\text { achievement learners used six self-regulated learning processes, including } \\
\text { metacognitive monitoring activities, learning strategies and indications of task } \\
\text { difficulty. }\end{array}$ \\
\hline $\begin{array}{l}\text { Greene and } \\
\text { Azevedo } \\
\text { (2009) }\end{array}$ & $\begin{array}{l}\text { Middle school } \\
\text { and high } \\
\text { school }\end{array}$ & $\begin{array}{l}\text { United } \\
\text { States }\end{array}$ & $\begin{array}{l}\text { Not } \\
\text { indicated }\end{array}$ & $\begin{array}{l}\text { The study examined how planning, monitoring, strategy use and handling of task } \\
\text { difficulty and demands were associated with the outcome of learning a complex } \\
\text { biological system through reading with hypermedia. Findings showed that } \\
\text { learners' monitoring behaviors were positively associated to the learning outcome. }\end{array}$ \\
\hline $\begin{array}{l}\text { Jiménez et al } \\
\text { (1995) }\end{array}$ & Sixth-grade & $\begin{array}{l}\text { United } \\
\text { States }\end{array}$ & L1 \& L2 & $\begin{array}{l}\text { The study compared the cognitive and metacognitive knowledge of a proficient } \\
\text { bilingual reader to that of a less proficient bilingual reader and a proficient }\end{array}$ \\
\hline
\end{tabular}




\begin{tabular}{|c|c|c|c|c|}
\hline & & & & $\begin{array}{l}\text { monolingual reader. It revealed that both the proficient bilingual reader and the } \\
\text { proficient monolingual reader used multiple cognitive and metacognitive } \\
\text { strategies strategically, while the less bilingual reader used the strategies in a } \\
\text { fragmented manner. Besides, the proficient bilingual reader used L1 and L2 as } \\
\text { mediating resources while the proficient bilingual reader considered bilingualism } \\
\text { as confusing. }\end{array}$ \\
\hline $\begin{array}{l}\text { Kendeou and } \\
\text { van den Broek } \\
\text { (2007) }\end{array}$ & Undergraduate & $\begin{array}{l}\text { United } \\
\text { States }\end{array}$ & $\begin{array}{l}\text { Not } \\
\text { indicated }\end{array}$ & $\begin{array}{l}\text { The study investigated the effects of prior knowledge and text structure on the } \\
\text { process of comprehending scientific texts. The results suggested that prior } \\
\text { knowledge and text structure were associated with participants' reading processes. }\end{array}$ \\
\hline $\begin{array}{l}\text { Linderholm } \\
\text { and Broek } \\
(2002)\end{array}$ & University & $\begin{array}{l}\text { United } \\
\text { States }\end{array}$ & $\begin{array}{l}\text { Not } \\
\text { indicated }\end{array}$ & $\begin{array}{l}\text { The study investigated how readers with low and high working memory adjusted } \\
\text { the reading process to fit the reading purpose. Results showed that the processes of } \\
\text { readers with low working memory capacity were less demanding than the other } \\
\text { group when the reading purpose was to study. However, when reading for } \\
\text { entertainment, patterns of processes were similar across readers. }\end{array}$ \\
\hline $\begin{array}{l}\text { Mateos et al } \\
\text { (2008) }\end{array}$ & Middle school & Spain & $\begin{array}{l}\text { Not } \\
\text { indicated }\end{array}$ & $\begin{array}{l}\text { The study explored the cognitive and metacognitive strategies used for learning to } \\
\text { write through reading informational texts in an online learning environment. It } \\
\text { also investigated the relation between the strategies and the written products. The } \\
\text { results show that to a large extent students lacked the cognitive and metacognitive } \\
\text { processes for learning writing strategically through reading. }\end{array}$ \\
\hline $\begin{array}{l}\text { De Milliano et } \\
\text { al (2016) }\end{array}$ & Middle school & Netherland & $\begin{array}{l}\text { Not } \\
\text { indicated }\end{array}$ & $\begin{array}{l}\text { This study examined the relationship between types and sequences of self- } \\
\text { regulated reading activities and the reading outcomes. Results showed that in } \\
\text { general the low-achievement learners were not frequently engaged in monitoring } \\
\text { their comprehension of the texts or making connections with prior knowledge. } \\
\text { However, among the low-achievement learners, those showing a straightforward } \\
\text { linear approach from orientation to question answering and readers who connected } \\
\text { text contents to prior knowledge more frequently yielded more success. }\end{array}$ \\
\hline $\begin{array}{l}\text { Moos and } \\
\text { Azevedo } \\
(2008)\end{array}$ & Undergraduate & $\begin{array}{l}\text { Not } \\
\text { indicated }\end{array}$ & $\begin{array}{l}\text { Not } \\
\text { indicated }\end{array}$ & $\begin{array}{l}\text { The study examined the impact of conceptual scaffolds on the process of self- } \\
\text { regulated learning through reading in a commercial hypermedia environment. } \\
\text { Results indicated that participants with and without scaffolds both decreased their } \\
\text { use of monitoring strategies while reading in the hypermedia learning task. In } \\
\text { addition, participants with scaffolds were found to use more of planning strategy } \\
\text { than without scaffolds. }\end{array}$ \\
\hline $\begin{array}{l}\text { Narvaez et al } \\
\text { (1999) }\end{array}$ & Undergraduate & $\begin{array}{l}\text { United } \\
\text { States }\end{array}$ & $\begin{array}{l}\text { Not } \\
\text { indicated }\end{array}$ & $\begin{array}{l}\text { The study investigated the influence of reading purpose on reading processes. } \\
\text { Findings showed that learners used more of strategies including evaluation of the } \\
\text { learning when reading with a study purpose than they did when reading with an } \\
\text { entertainment purpose. This pattern was stronger when learners read the }\end{array}$ \\
\hline
\end{tabular}




\begin{tabular}{|l|l|l|l|l|}
\hline & & & & expository text than they did when they read the narrative text. \\
\hline Rogers (1991) & Ninth-grade & $\begin{array}{l}\text { United } \\
\text { States }\end{array}$ & $\begin{array}{l}\text { Not } \\
\text { indicated }\end{array}$ & $\begin{array}{l}\text { This study examined the influence of an instructional unit on learners self- } \\
\text { regulated reading processes. Results showed that the instructional unit led to a } \\
\text { shift in self-regulated reading strategy use, such as questioning and evaluating. }\end{array}$ \\
\hline Scott (2008) & Fourth-grade & $\begin{array}{l}\text { United } \\
\text { States }\end{array}$ & $\begin{array}{l}\text { Not } \\
\text { indicated }\end{array}$ & $\begin{array}{l}\text { The study examined the richness of self-regulated reading data collected through 4 } \\
\text { assessment methods, think-aloud, interview, error detection and questionnaire. } \\
\text { Results indicated that think-aloud and interview generated a greater number and } \\
\text { broader range of reading processing responses and think-aloud protocols } \\
\text { generated more data regarding metacognitive processing. }\end{array}$ \\
\hline $\begin{array}{l}\text { van den Broek } \\
\text { et al (2001) }\end{array}$ & Undergraduate & $\begin{array}{l}\text { United } \\
\text { States }\end{array}$ & $\begin{array}{l}\text { Not } \\
\text { indicated }\end{array}$ & $\begin{array}{l}\text { The study investigated the effects of reading goals on cognitive and meta- } \\
\text { cognitive processes for reading. The results indicate that readers with an } \\
\text { entertainment goal were more likely to make monitoring responses than those } \\
\text { preparing for an exam. }\end{array}$ \\
\hline
\end{tabular}

Appendix II: Design of think-aloud protocol in the studies where it was used for data collection

\begin{tabular}{|c|c|c|c|c|c|c|c|c|c|}
\hline \multirow[t]{2}{*}{ Paper } & \multicolumn{4}{|c|}{ Verbalization Content Required in Instruction } & \multicolumn{2}{|c|}{$\begin{array}{l}\text { Demonstration } \\
\text { or Practice? }\end{array}$} & \multicolumn{3}{|c|}{ Prompting } \\
\hline & $\begin{array}{l}\text { Verbalize } \\
\text { everything }\end{array}$ & $\begin{array}{l}\text { No mention of } \\
\text { verbalizing } \\
\text { everything }\end{array}$ & $\begin{array}{l}\text { Do not justify } \\
\text { behavior. }\end{array}$ & $\begin{array}{l}\text { No mention } \\
\text { of } \\
\text { verbalization } \\
\text { content } \\
\text { requirement }\end{array}$ & Yes & No & $\begin{array}{l}\text { In } \\
\text { practice }\end{array}$ & $\begin{array}{l}\text { While } \\
\text { thinking } \\
\text { aloud }\end{array}$ & $\begin{array}{l}\text { No } \\
\text { prompting }\end{array}$ \\
\hline $\begin{array}{l}\text { Azevedo et al } \\
\text { (2005) }\end{array}$ & $\sqrt{ }$ & & & & & $\sqrt{ }$ & & $\sqrt{ }$ & \\
\hline $\begin{array}{l}\text { Azevedo, } \\
\text { Cromley, et al } \\
\text { (2004) }\end{array}$ & $\sqrt{ }$ & & & & $\sqrt{ }$ & & & $\sqrt{ }$ & \\
\hline $\begin{array}{l}\text { Azevedo et al } \\
(2007)\end{array}$ & $\sqrt{ }$ & & & & & $\sqrt{ }$ & & $\sqrt{ }$ & \\
\hline $\begin{array}{l}\text { Azevedo, } \\
\text { Guthrie, et al } \\
\text { (2004) }\end{array}$ & $\sqrt{ }$ & & & & $\sqrt{ }$ & & & $\sqrt{ }$ & \\
\hline $\begin{array}{l}\text { Azevedo et al } \\
\text { (2008) }\end{array}$ & $\sqrt{ }$ & & & & $\sqrt{ }$ & & & $\sqrt{ }$ & \\
\hline Barnett (1998) & & & $\sqrt{ }$ & & $\sqrt{ }$ & & & $\sqrt{ }$ & \\
\hline
\end{tabular}




\begin{tabular}{|c|c|c|c|c|c|c|c|c|c|}
\hline $\begin{array}{l}\text { Bråten and } \\
\text { Strømsø } \\
\text { (2003) }\end{array}$ & $\sqrt{ }$ & & & & $\sqrt{ }$ & & & $\sqrt{ }$ & \\
\hline $\begin{array}{l}\text { Coiro and } \\
\text { Dobler (2007) }\end{array}$ & & $\sqrt{ }$ & & & & $\sqrt{ }$ & & $\sqrt{ }$ & \\
\hline $\begin{array}{l}\text { Denton et al } \\
\text { (2015) }\end{array}$ & $\sqrt{ }$ & & & & $\sqrt{ }$ & & & $\sqrt{ }$ & \\
\hline $\begin{array}{l}\text { Fadlelmula } \\
\text { (2010) }\end{array}$ & & & $\sqrt{ }$ & & & $\sqrt{ }$ & & & $\sqrt{ }$ \\
\hline $\begin{array}{l}\text { Goldma et al } \\
\text { (2012) }\end{array}$ & $\sqrt{ }$ & & & & $\sqrt{ }$ & & & $\sqrt{ }$ & \\
\hline Greene (2007) & $\sqrt{ }$ & & & & $\sqrt{ }$ & & & $\sqrt{ }$ & \\
\hline $\begin{array}{l}\text { Greene and } \\
\text { Azevedo } \\
\text { (2009) }\end{array}$ & & & & $\sqrt{ }$ & & $\sqrt{ }$ & & $\sqrt{ }$ & \\
\hline $\begin{array}{l}\text { Jiménez et al } \\
\text { (1995) }\end{array}$ & & & & $\sqrt{ }$ & $\sqrt{ }$ & & $\sqrt{ }$ & & \\
\hline $\begin{array}{l}\text { Kendeou and } \\
\text { van den Broek } \\
\text { (2007) }\end{array}$ & & $\sqrt{ }$ & & & $\sqrt{ }$ & & $\sqrt{ }$ & & \\
\hline $\begin{array}{l}\text { Linderholm } \\
\text { and Broek } \\
(2002)\end{array}$ & & & & $\sqrt{ }$ & & $\sqrt{ }$ & & $\sqrt{ }$ & \\
\hline $\begin{array}{l}\text { Mateos et al } \\
\text { (2008) }\end{array}$ & $\sqrt{ }$ & & & & $\sqrt{ }$ & & & $\sqrt{ }$ & \\
\hline $\begin{array}{l}\text { De Milliano et } \\
\text { l (2016) }\end{array}$ & & $\sqrt{ }$ & & & $\sqrt{ }$ & & & $\sqrt{ }$ & \\
\hline $\begin{array}{l}\text { Moos and } \\
\text { Azevedo } \\
\text { (2008) }\end{array}$ & $\sqrt{ }$ & & & & & $\sqrt{ }$ & & $\sqrt{ }$ & \\
\hline $\begin{array}{l}\text { Narvaez et al } \\
\text { (1999) }\end{array}$ & $\sqrt{ }$ & & & & $\sqrt{ }$ & & $\sqrt{ }$ & & \\
\hline $\begin{array}{l}\text { T. Rogers } \\
\text { (1991) }\end{array}$ & $\sqrt{ }$ & & & & & $\sqrt{ }$ & & $\sqrt{ }$ & \\
\hline Scott (2008) & $\sqrt{ }$ & & & & $\sqrt{ }$ & & & $\sqrt{ }$ & \\
\hline
\end{tabular}




\begin{tabular}{|l|l|l|l|l|l|l|l|l|l|l|l|}
\hline $\begin{array}{l}\text { van den Broek } \\
\text { et al (2001) }\end{array}$ & $\sqrt{ }$ & & & & $\sqrt{ }$ & & & & & & \\
\hline
\end{tabular}

Appendix III: Possible problems of think-aloud protocol and suggested solutions

\begin{tabular}{|l|l|}
\hline Possible problems & Suggested solutions \\
\hline $\begin{array}{l}\text { Problems in general: unclear } \\
\text { reactivity and veridicality }\end{array}$ & $\begin{array}{l}\text { - Provide details of demographical information of participants and think-aloud task design in } \\
\text { the studies deploying think-aloud protocols; } \\
\text { - Take reactivity and validity of think-aloud protocols into consideration when potential } \\
\text { limitations of relevant studies are discussed; } \\
\text { - Always view think-aloud data as indicators of only a part of self-regulated reading process } \\
\text { rather than a full picture of it. }\end{array}$ \\
\hline $\begin{array}{l}\text { Problems of latency and } \\
\text { incompleteness: The reaction } \\
\text { time may be increase by think- } \\
\begin{array}{l}\text { aloud protocol and the } \\
\text { verbalization may be incomplete. }\end{array}\end{array}$ & $\begin{array}{l}\text { - Train participants before the actual administration of think-aloud tasks; } \\
\text { - Provide participants with clear instruction of, demonstration on, and chance to practice } \\
\text { thinking aloud; } \\
\text { - Avoid over-demonstrating or over-practicing; } \\
\text { - Discourage participants from justifying or explaining their behaviors; } \\
\text { - Combine one or more other data sources for an accurate and complete picture such as pre- and } \\
\text { post- interviews, questionnaires, observations, on-line computer logs, and eye-movement } \\
\text { registration; } \\
\text { - Prompt participants to think aloud by placing markers. }\end{array}$ \\
\hline $\begin{array}{l}\text { Problems of accuracy: Think- } \\
\text { aloud protocol may change } \\
\text { participants' reading processes or } \\
\text { reading outcomes. }\end{array}$ & $\begin{array}{l}\text { - Use tasks other than reading for demonstration or practice; } \\
\text { - For demonstration or practice, use reading texts different from those used in the think-aloud } \\
\text { tasks; } \\
\text { - Give all participants the same examples for demonstration or practice. }\end{array}$ \\
\hline
\end{tabular}




\section{References}

Afflerbach, P., \& Johnston, P. (1984). Research methodology on the use of verbal reports in reading research. Journal of Reading Behavior, 16(4), 307-322. http://doi.org/10.1080/10862968409547524

Azevedo, R., Cromley, J. G., \& Seibert, D. (2004). Does adaptive scaffolding facilitate students' ability to regulate their learning with hypermedia? Contemporary Educational Psychology, 29, 344-370. http://doi.org/10.1016/j.cedpsych.2003.09.002

Azevedo, R., Cromley, J. G., Winters, F. I., Moos, D. C., \& Greene, J. A. (2005). Adaptive human scaffolding facilitates adolescents' self-regulated learning with hypermedia. Instructional Science, 33(5-6), 381-412. http://doi.org/10.1007/s11251-005-1273-8

Azevedo, R., Greene, J. A., \& Moos, D. C. (2007). The effect of a human agent's external regulation upon college students' hypermedia learning. Metacognition and Learning, 2(2-3), 67-87. http://doi.org/10.1007/s11409-007-9014-9

Azevedo, R., Guthrie, J., \& Seibert, D. (2004). The role of self-regulated learning in fostering students' conceptual understanding of complex systems with hypermedia. Journal of Educational Computing Research, 30(1-2), 87-111. http://doi.org/10.2190/DVWX-GM1T-6THQ-5WC7

Azevedo, R., Moos, D. C., Greene, J. A., Winters, F. I., \& Cromley, J. G. (2008). Why is externallyfacilitated regulated learning more effective than self-regulated learning with hypermedia? Educational Technology Research and Development, 56(1), 45-72. http://doi.org/DOI 10.1007/s 11423-007-9067-0

Baker, L., \& Brown, A. L. (1984). Metacognitive skills and reading. Handbook of reading research, 1(353), V394.

Bannert, M., \& Mengelkamp, C. (2008). Assessment of metacognitive skills by means of instruction to think aloud and reflect when prompted. Does the verbalisation method affect learning? Metacognition and Learning, 3(1), 39-58.

Barkaoui, K. (2011). Think-aloud protocols in research on essay rating: An empirical study of their veridicality and reactivity. Language Testing, 28(1), 51-75. http://doi.org/10.1177/0265532210376379

Barnett, J. E. (1998). Self-regulation of textbook reading: A think-aloud study. In Paper presented at the Annual Meeting of the American Educational Research Association. San Diego. http://doi.org/ED419696

Baumann, J. F., Seifert-Kessell, N., \& Jones, L. A. (1992). Effect of think-aloud instruction on elementary students' comprehension monitoring abilities. Journal of Literacy Research, 24(2), 143172. http://doi.org/10.1080/10862969209547770

Bernacki, M. L., Byrnes, J. P., \& Cromley, J. G. (2012). The effects of achievement goals and selfregulated learning behaviors on reading comprehension in technology-enhanced learning environments. Contemporary Educational Psychology, 37(2), 148-161. http://doi.org/10.1016/j.cedpsych.2011.12.001

Bowles, M. A. (2010a). Concurrent verbal reports in second language acquisition research. Annual Review of Applied Linguistics, 3010, 111-127. http://doi.org/10.1017/S0267190510000036

Bowles, M. A. (2010b). The think-aloud controversy in second language research. New York: Routledge.

Bowles, M. A., \& Leow, R. P. (2005). Reactivity and type of verbal report in SLA expanding the scope of investigation, 27, 415-440.

Branch, J. L. (2001). Junior high students and think alouds: Generating information-seeking process data 
using concurrent verbal protocols. Library and Information Science Research, 23(2), 107-122. http://doi.org/10.1016/S0740-8188(01)00065-2

Bråten, I., \& Samuelstuen, M. S. (2004). Does the influence of reading purpose on reports of strategic text processing depend on students' topic knowledge? Journal of Educational Psychology, 96(2), 324336. http://doi.org/10.1037/0022-0663.96.2.324

Bråten, I., \& Strømsø, H. I. (2003). A longitudinal think-aloud study of spontaneous strategic processing during the reading of multiple expository texts. Reading and Writing, 16(3), 195-218.Brunfaut, T., \& McCray, G. (2015). Looking into test-takers' cognitive processes while completing reading tasks: a mixed-method eye-tracking and stimulated recall study. Retrieved from http://eprints.lancs.ac.uk/72005/1/Brunfaut_and_McCray_final_report_FINAL.pdf

Chuang, M.-T. (2007). Cross-language transfer: The strategic reading processes of eighth-grade Taiwanese readers in Chinese and English within a self-regulated learning framework (Unpublished doctoral thesis). University of Maryland, College Park, United States.

Coiro, J., \& Dobler, E. (2007). Exploring the online reading comprehension strategies used by sixth-grade skilled readers to search for and locate information on the Internet. Reading Research Quarterly, 42(2), 214-257. http://doi.org/10.1598/RRQ.42.2.2

Crain-Thoreson, C., Lippman, M. Z., \& McClendon-Magnuson, D. (1997). Windows on comprehension: Reading comprehension processes as revealed by two think-aloud procedures. Journal of Educational Psychology, 89(4), 579-591. http://doi.org/10.1037/0022-0663.89.4.579

Cromley, J. G., \& Azevedo, R. (2006). Self-report of reading comprehension strategies: What are we measuring? Metacognition and Learning, 1, 229-247. http://doi.org/10.1007/s11409-006-9002-5

Cumming, A., Kantor, R., \& Powers, D. E. (2002). Decision making while rating ESL/EFL writing tasks: A descriptive framework. The Modern Language Journal, 86(1), 67-96. http://doi.org/10.1111/1540-4781.00137

de Milliano, I., van Gelderen, A., \& Sleegers, P. (2016). Types and sequences of self-regulated reading of low-achieving adolescents in relation to reading task achievement. Journal of Research in Reading, 39(2), 229-252. http://doi.org/10.1111/1467-9817.12037

Denton, C. A., Enos, M., York, M. J., Francis, D. J., Barnes, M. A., Kulesz, P. A., ... Carter, S. (2015). Text-processing differences in adolescent adequate and poor comprehenders reading accessible and challenging narrative and informational text. Reading Research Quarterly, 50(4), 393-416. http://doi.org/10.1002/rrq.105

Ericsson, K. A., \& Simon, H. A. (1993). Protocol analysis: Verbal report as data. Cambridge, Massachusetts, London, England: The MIT Press.

Fadlelmula, F. K. (2010). How a learner self-regulates reading comprehension: A case study for graduate level reading. US-China Education Review, 7(10), 22-29.

Goldma, S. R., Braasch, J. L. G., Wiley, J., Graesser, A. C., \& Brodowinska, K. (2012). Comprehending and learning from internet sources: Processing patterns of better and poorer learners. Reading Research Quarterly, 47(4), 356-381. http://doi.org/10.1002/RRQ.027

Grabe, W. (2009). Reading in a second language: Moving from theory to practice. New York: Cambridge University Press.

Greene, J. A. (2007). Adolescents' use of self-regulatory processes and their relation to qualitative mental model shifts while using hypermedia. Journal of Educational Computing Research, 36(2), 125-148. 
Greene, J. A., \& Azevedo, R. (2009). A macro-level analysis of SRL processes and their relations to the acquisition of a sophisticated mental model of a complex system. Contemporary Educational Psychology, 34(1), 18-29. http://doi.org/10.1016/j.cedpsych.2008.05.006

Griffiths, C. (2015). What have we learnt from “ good language learners ”? ELT Journal, 69(4), 425-433. http://doi.org/10.1093/elt/ccv040

Jiménez, R. T., García, G. E., \& Pearson, P. D. (1995). Three children, two languages, and strategic reading: Case studies in bilingual/monolingual reading. American Educational Research Journal, 32(1), 67-97.

Juliebo, M., Malicky, G., \& Norman, C. (1998). Metacognition of young readers in an early intervention programme. Journal of Research in Reading, 21(1), 24-35. http://doi.org/10.1111/1467-9817.00040

Kendeou, P., \& van den Broek, P. (2007). The effects of prior knowledge and text structure on comprehension processes during reading of scientific texts. Memory \& Cognition, 35(7), 1567-1577. http://doi.org/10.3758/BF03193491

Kinnunen, R., \& Vauras, M. (1995). Comprehension monitoring and the level of comprehension in highand low-achieving primary school children's reading. Learning and Instruction, 5(2), 143-165. http://doi.org/10.1016/0959-4752(95)00009-R

Linderholm, T., \& van den Broek, P. (2002). The effects of reading purpose and working memory capacity on the processing of expository text. Journal of Educational Psychology, 94(4), 778-784. http://doi.org/10.1037//0022-0663.94.4.778

Liyanage, I., \& Bartlett, B. J. (2011). Gender and language learning strategies: looking beyond the categories. The Language Learning Journal, 40(2), 237-253. http://doi.org/10.1080/09571736.2011.574818

Mateos, M., Martín, E., Villalón, R., \& Luna, M. (2008). Reading and writing to learn in secondary education: Online processing activity and written products in summarizing and synthesizing tasks. Reading and Writing, 21(7), 675-697. http://doi.org/10.1007/s11145-007-9086-6

Moos, D. C., \& Azevedo, R. (2008). Monitoring, planning, and self-efficacy during learning with hypermedia: The impact of conceptual scaffolds. Computers in Human Behavior, 24(4), 1686-1706. http://doi.org/10.1016/j.chb.2007.07.001

Narvaez, D., van den Broek, P., \& Ruiz, A. B. (1999). The influence of reading purpose on inference generation and comprehension in reading. Journal of Educational Psychology, 91(3), 488-496.

Pintrich, P., \& Zusho, A. (2002). The development of academic self-regulation: The role of cognitive and motivational factors. In A. Wigfield \& J. Eccles (Eds.), Development of achievement motivation (pp. 249-284). San Diego: Academic Press.

Pressley, M., \& Afflerbach, P. (1995). Verbal protocols of reading: The nature of constructively responsive reading. Hillsdale: Lawrence Erlbaum Associates.

Rayner, K. (2009). Eye movements and attention in reading, scene perception, and visual search. The Quarterly Journal of Experimental Psychology (Vol. 62). http://doi.org/10.1080/17470210902816461Richter, T., \& Schmid, S. (2010). Epistemological beliefs and epistemic strategies in self-regulated learning. Metacognition and Learning, 5(1), 47-65. http://doi.org/10.1007/s11409-009-9038-4

Robinson, K. M. (2001). The validity of verbal reports in children's subtraction. Journal of Educational Psychology, 93(1), 211-222. 
Rogers, J., Révész, A., \& Rebuschat, P. (2016). Implicit and explicit knowledge of L2 inflectional morphology. $\quad$ Applied $\quad$ Psycholinguistics, $\quad 37(4), \quad 781-812$. http://doi.org/10.1017/CBO9781107415324.004

Rogers, T. (1991). Students as literary critics: The interpretive experiences, beliefs, and processes of ninth-grade students. Journal of Literacy Research, 23(4), 391-423. http://doi.org/10.1080/10862969109547751

Roohani, A., \& Asiabani, S. (2015). Effects of self-regulated strategy development on EFL learners' reading comprehension and metacognition. GEMA Online Journal of Language Studies, 15(3), 3149.

Scott, D. B. (2008). Assessing text processing: A comparison of four methods. Journal of Literacy Research, 40(3), 290-316. http://doi.org/10.1080/10862960802502162

van den Broek, P., Lorch, R. F. J., Linderholm, T., \& Gustafson, M. (2001). The effects of readers' goals on inference generation and memory for texts. Memory \& Cognition, 29(8), 1081-1087.

Veenman, M. V. J. (2005). The assessment of metacognitive skills: What can be learned from multimethod designs? In B. Moschner \& C. Artelt (Eds.), Lernstrategien und Metakognition: Implikationen für Forschung und Praxis (pp. 75-97). Berlin: Waxmann.

Veenman, M. V. J., \& Spaans, M. A. (2005). Relation between intellectual and metacognitive skills: Age and task differences. Learning and Individual Differences, 15(2), 159-176. http://doi.org/10.1016/j.lindif.2004.12.001

Veenman, M. V. J., van Hout-Wolters, B. H., \& Afflerbach, P. (2006). Metacognition and learning: Conceptual and methodological considerations. Metacognition and Learning, 1(1), 3-14. http://doi.org/10.1007/s11409-006-6893-0

Veenman, M. V. J., Wilhelm, P., \& Beishuizen, J. J. (2004). The relation between intellectual and metacognitive skills from a developmental perspective. Learning and Instruction, 14(1), 89-109. http://doi.org/10.1016/j.learninstruc.2003.10.004

Yang, C., \& Zhang, L. J. (2015). Methodological considerations in second language writing research: A critical appraisal of the think-aloud technique. Second Language Learning Research, 1, 41-50.

Yoshida, M. (2008). Think-aloud protocols and type of reading task: The issue of reactivity in L2 reading research. In M. Bowles (Ed.), Second Language Research Forum (pp. 199-209). Somerville, MA: Cascadilla Proceedings Project.

Zhang, L. J. (2008). Constructivist pedagogy in strategic reading instruction: Exploring pathways to learner development in the English as a second language (ESL) classroom. Instructional Science, 36(2), 89-116. http://doi.org/10.1007/s11251-007-9025-6 